\title{
The General Work Procedure Model For THE SERVICE PRODUCT
}

\author{
Cosic, I.; RADAKOVIC, N.; LALIC, B. \& SimEUnOVIC, N.
}

Abstract: Even though the services have more and more important role in the society, the productivity of this is much smaller then the productivity of the production sector. Most of the study predicts that in the next decade, the productivity of the service sector will grow at a rate of only 0.5 percent annually compared to 3.3 percent in manufacturing industry.

The aim of this research is to show that the developed model procedures of the manufacturing industry can be applied to other categories of production, which would achieve a great improvement, before all in the service production.

The work procedure of planning the service product by applying the general work procedure for different types of products, based on analyzed similarities and differences of the product itself and the process of the four generic groups of products classified in ISO 9000:2000, is shown in this work.

This paper resolves the problem of knowledge structuring in the field of manufacturing industry and adjustments for application in service production.

Keywords: demands, service, productivity
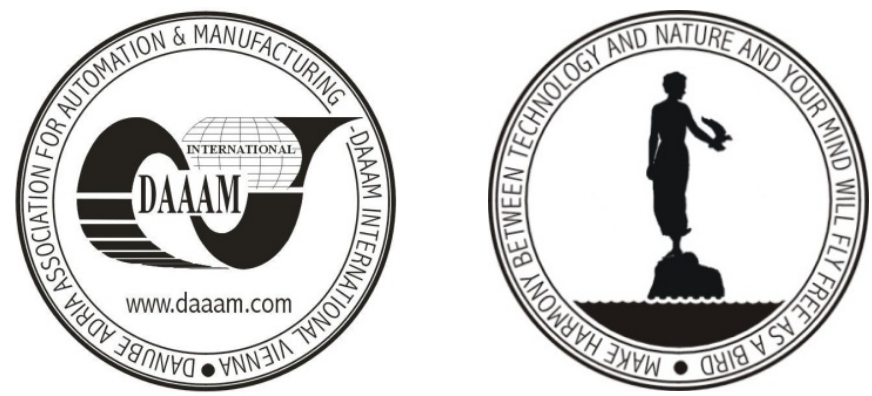

Authors' data: Prof. dr Cosic I[lija]; Prof. dr Radakovic N[ikola]; Mr. Lalic B[ojan]; Mr. Simeunovic N[enad], University of Novi Sad, Faculty of Technical Sciences, Trg Dositeja Obradovica 6, 21000 Novi Sad, Serbia, ftndean@uns.ac.rs, nikola@iis.ns.ac.yu,nsimeun@uns.ac.rs, blalic@uns.ac.rs

This Publication has to be referred as: Cosic, I[lija]; Radakovic, N[ikola]; Lalic, B[ojan] \& Simeunovic, N[enad] (2009). The General Work Procedure Model for the Service Product, Chapter 30 in DAAAM International Scientific Book 2009, pp. 281288, B. Katalinic (Ed.), Published by DAAAM International, ISBN 978-3-90150969-8, ISSN 1726-9687, Vienna, Austria

DOI: $10.2507 /$ daaam.scibook.2009.30 